\title{
ANALISIS PERTANYAAN PADA BUTIR SOAL READING COMPREHENSION PADA TEST TOEIC
}

\author{
Endang Fauziati \\ Universitas Muhammadiyah Surakarta \\ Endang.fauziati@ums.ac.id
}

\begin{abstract}
ABSTRAK
Penelitian mengenai model test TOEIC ini bertujuan untuk mendapatkan deskripsi dan penjelasan yang komprehensif mengenai sejumlah aspek yang terkait dengan butir butir soal yang ada. Penelitian ini bertujuan untuk: (1) mendeskripsikan pola pertanyaan pada butir soal Completion dan Error Recognition pada Reading TOEIC, (2) mendeskripsikan konteks bacaan pada soal pemahaman teks Reading TOEIC, (3) mendeskripsikan pola pertanyan pada butir soal pemahaman teks pada Reading TOEIC, dan (4) memaparkan frekuensi masing masing tipe pertanyaan pada butir soal pemahaman teks pada Reading. Lingkup penelitian ini adalah model test TOEIC, khususnya structure dan reading comprehension yang diambil dari beberapa buku latihan test TOEIC. Data terdiri dari 500 butir soal yang yang diambil dari buku latihan TOEIC yang diterbitkan oleh Barron's Educational Series, Prentice Hall, dan Longman. Teknik pengumpulan data berupa teknik dokumentasi. Data dianalisis dengan metode deskriptif interpretatif. Hasil penelitian menunjukkan sebagai berikut: (1) komponen linguistik yang ditanyakan pada bagian Completion and Error recognition meliputi pertanyaan tentang penguasaan vocabulary (54.34\%), Class of words (15\%) (Verb, Noun, Adjective), Verb tense (11.33\%), determiner (5.33\%) preposition (4\%), conjunction (3.67\%), Degree of comparison in Adjective (3.33\%), dan Conditional sentence (3\%); (2) Konteks bacaan pada butir soal Reading Comprehension meliputi bisnis, manufacturing, finance and Budgeting, Offices, personnel, purchasing, housing/corporate property, travel, dining out, entertainment, dan Health; (3) pola pertanyaan Reading Comprehension meliputi: (a) gagasan utama dan kemungkinan judul yang tepat, (b) informasi yang tersurat dalam teks, (c) informasi yang tersirat, dan (d) dan tujuan penulisan. Berdasarkan hasil penelitian di atas disimpulkan bahwa penguasaan kosakata sangat penting untuk keberhasilan dalam test TOEIC karena 50\%-nya berupa penguasaan kosakata.
\end{abstract}

Kata kunci: test TOEIC, butir butir soal, tata bahasa, pemahaman teks

\begin{abstract}
This research is aimed to obtain a comprehensive description on aspects related to the TOEIC test items, as follows: (1) the question pattern of Completion and Error Recognition section; (2) the context of reading text in Reading Comprehension section; (3) the pattern of the question on reading Comprehension section; (4) the frequency of each type of question in Reading section. The scope of this study is the TOEIC model test, especially the structure and reading section. The data consists of 500 test items taken from TOEIC preparation books published by Barron's Educational
\end{abstract}


Series, Prentice Hall, and Longman. Data collection techniques used in this study is documentation techniques. The data analysis technique used is descriptive interpretative. The results are as follows: (1) the linguistic components questioned in the Completion and Error recognition section include vocabulary (54.34\%), Class of words (15\%), Verb tense (11.33\%), determiner (5.33\%) preposition (4\%), conjunction (3.67\%), degree of comparison in adjective (3.33\%), and conditional sentence (3\%); (2) Context of reading text in Reading Comprehension section covers business, manufacturing, finance and budgeting, Offices, personnel, purchasing, housing, travel, dining out, entertainment, and Health; (3) aspects questioned in Reading Comprehension section include: (a) the main idea and the possibility of proper title, (b) the information is written in the text, (c) information between the lines, (d) and the purpose of writing. Based on the results, it is concluded that mastery of vocabulary is essential for success in the TOEIC test since it occupies 50\% of the test.

Keywords: TOEIC, item test, structure, reading comprehension

\section{PENDAHULUAN}

Evaluasi merupakan salah satu komponen penting dalam proses pendidikan, utamanya untuk mengukur keberhasilan suatu program pendidikan dan pengajaran. Dalam pengajaran bahasa Inggris (selanjutnya B-Ing), tes digunakan sebagai alat evaluasi untuk mengukur keberhasilan proses belajar mengajar B-Ing. Tes semacam ini dapat berupa tes baku (standardized test seperti TOEFL, IELTS, TOEIC) atau tes yang dibuat oleh pengajar sendiri. TOEIC (Test of English for International Communication) telah banyak digunakan secara luas, skala internasional karena validitas dan reliabilitasnya telah diakui secara internasional. Lebih dari 40 universitas dan colleges di Jepang menggunakan TOEIC sebagai placement tool dan sebagai syarat kelulusan mahasiswa (Tonegawa, 2005). Model tes ini juga telah diaplikasikan di Universitas Muhammadiyah Surakarta sebagai alat ukur kemampuan berbahasa Inggris para mahasiswa.

TOEIC dirancang khusus untuk mengukur kemampuan bahasa Inggris untuk komunikasi sehari-hari dalam konteks pekerjaan di lingkungan internasional. TOEIC ini terdiri dari tes untuk keterampilan mendengarkan (listening skill) dan membaca (reading skill). Tes ini dirancang dalam bentuk pilihan ganda, terdiri dari 200 pertanyaan yang meliputi 100 pertanyaan pemahaman pendengaran dan 100 pertanyaan pemahaman bacaan.

Mulai tahun 2009 Universitas Muhammadiyah Surakarta melalui SK Rektor NO 088/ II/2009 memberlakukan kurikukum baru MKU Bahasa Inggris. Kurikulum ini didesain sedemikian rupa sehingga kemampuan Bahasa Inggris lulusan terukur dengan standar internasional. Untuk itu, TOEIC telah dipilih sebagai parameter pencapaian kompetensi bahasa Inggris lulusan UMS dengan standar kelulusan 400. Kebijakan ini dicantumkan pada sasaran mutu UMS Tanggal 12 Agustus 2009, NO 3) bahwa "Lulusan memiliki kompetensi Bahasa Inggris $\geq 450$ (Elementary Proficiency Plus), diukur dengan TOEIC".

Dari sejak pertama kali (tahun 2009) TOEIC dijadikan sebagai acuan keterampilan berbahasa Inggris lulusan UMS, terlihat jelas bagaimana kemampuan bahasa Inggris lulusan UMS ini. Bukan hal yang mudah bagi mahasiswa UMS untuk memperoleh skor minimal 400 sebagaimana hasil pencapaian skor TOEIC oleh mahasiswa UMS adalah sebagai berikut. 


\begin{tabular}{cccccc}
\hline No. & Tahun & $\begin{array}{c}\text { Jumlah } \\
\text { Mhs. }\end{array}$ & $\begin{array}{c}\text { Kelulusan dengan skor } \geq \\
400 \text { (Ujian ke-I) }\end{array}$ & $\begin{array}{c}\text { Kelulusan dg skor } \\
\geq 400\end{array}$ (Ujian ke-II) & $\begin{array}{c}\text { Total } \\
\text { Kelulusan }\end{array}$ \\
\hline 1 & 2009 & 4853 & 650 & 427 & 1077 \\
2 & 2010 & 5062 & 648 & 124 & 772 \\
3 & 2011 & 4714 & 735 & & \\
\hline
\end{tabular}

Sebelum diberlakukan kebijakan TOEIC 400 sebagai prasyarat ujian skripsi, umumnya para mahasiswa hanya melewati proses pembelajaran Bahasa Inggris biasa. Artinya, they just take it for granted karena asal rajin kuliah pasti lulus. Materi tes tidak terstandar secara internasional.

Data di atas menunjukkan bahwa pencapaian score TOEIC masih kurang memuaskan. Oleh karena itu, sebagai pendidik, peneliti merasa berkewajiban untuk terus berusaha mencari solusi agar kertampilan bahasa Inggris lulusan meningkat; setidaknya hal yang telah dicantumkan dalam sasaran mutu UMS dapat terealisasi dengan baik. Berbagai usaha telah dilakukan untuk peningkatan keterampilan berbahasa Inggris mahasiswa, antara lain peningkatan proses belajarmengajar maupun fasilitasnya, pengadaan kursus, dan analisis butir soal TOEIC. Penelitian tentang pola pertanyaan reading skill TOEIC ini bertujuan untuk memberikan feedback kepada para dosen sehingga mereka dapat memberikan perkuliahan yang sesuai dengan kebutuhan mahasiswa.

Banyak penelitian yang telah dilakukan terkait dengan TOEIC. Salah satu penelitian tentang TOEIC dilakukan oleh Yeonsuk Cho dan Brent Bridgeman (2010) yang mengkaji hubungan antara skor Bahsa Inggris (TOEIC, TOEFL) dengan kinerja akademik mahasiswa di beberapa universitas di Amerika. Kinerja akademik di perguruan tinggi didefinisikan sebagai nilai ratarata (IPK). Catatan akademis untuk 2.594 mahasiswa sarjana dan pascasarjana dikumpulkan dari 10 universitas di Amerika Serikat. Data terdiri dari siswa, IPK, informasi program rinci, dan skor tes TOEIC, TOEFL, GRE, GMAT, dan nilai SAT. Analisis Korelasi dilakukan untuk subkelompok dengan status akademik dan disiplin yang berbeda. Grafik juga digunakan untuk melengkapi model korelasi berbasis analisis dengan menghadirkan validitas prediktif pada masing masing individu di salah satu subkelompok skor bahasa Inggris milik salah satu subkelompok IPK. Validitas prediktif yang dinyatakan dalam korelasi tidak tampak signifikan. Meskipun demikian, pola umum yang ditunjukkan dalam grafik menunjukkan bahwa siswa dengan skor Bahasa Inggris tinggi cenderung mendapatkan GPAs lebih tinggi. Konklusinya adalah bahwa test bahasa Inggris memberikan informasi tentang kinerja akademik mahasiswa.

Penelitian lain dilakukan di Jepang oleh Iwabe (2005) dari Universitas Yamaguci. Di universitas ini TOEIC diadopsi sebagai persyaratan kelulusan dengan skor minimal. Sebelum TOEIC dijadikan persyaratan kelulusan, mahasiswa cukup mengikuti pelajaran di kelas agar bisa lulus, tetapi setelah universitas mengadopsi TOEIC sebagai persyaratan kelulusan, para mahasiswa perlu belajar bahasa Inggris selama beberapa tahun agar lulus. Iwabe juga melaporkan bahwa mahasiswa menghabiskan banyak waktu untuk pekerjaan rumah sebelum dan sesudah program TOEIC dilaksanakan di Yamaguchi University. Namun, mayoritas mahasiswa menyatakan bahwa waktu untuk studi bahasa Inggris meningkat rata-rata $300 \%$. mereka juga menyatakan bahwa waktu yang dihabiskan untuk belajar mata pelajaran yang lain juga naik. Dari penelitian ini, Iwabe mengasumsikan bahwa mahasiswa memperoleh kebiasaan belajar yang positif di bidang bahasa Inggris dan berdampak pada mata kuliah lain.

Penelitian tentang model test TOEIC sekarang ini terbatas pada butir soal Reading Skill. Model tes dalam hal ini juga dibatasi pada model tes yang terdapat pada buku buku latihan TOEIC yang diterbitkan oleh Longman, Barron, and Prentice Hall. Penelitian ini bertujuan 
untuk mendapatkan deskripsi dan penjelasan yang lengkap mengenai sejumlah aspek yang terkait dengan butir soal pada reading skill for TOEIC. Adapun yang dimaksud dengan pola di sini adalah kecenderungan pertanyaan dalam Tes TOEIC yang menjadi kekhasan. Sejalan dengan itu, secara rinci penelitian ini bertujuan untuk (1) mendeskripsikan pola pertanyaan pada butir soal Completion dan Error Recognition; mendeskripsikan pola pertanyaan pada butir soal pemahaman teks; mendeskripsikan konteks bacaan pada soal pemahaman teks; dan mendeskripsikan pola pertanyan pada butir soal pemahaman teks.

Penelitian ini sangat bermanfaat utamanya untuk memperluas khazanah keilmuan yang terkait dengan ilmu pengetahuan tentang tes bahasa. Adapun manfaat yang diperoleh langsung dari kegiatan analisis TOEIC ini adalah sebagai berikut: (1) Hasil analisis dapat dijadikan rujukan para dosen dalam mengajarkan Bahasa Inggris (TOEIC preparation); (2) Para dosen dapat menentukan bagian mana yang semestinya diberikan penekanan dalam memberikan materi; (3) Para dosen mampu membantu meningkatkan pencapaian nilai TOEIC mahasiswa; dan (4) para mahasiswa sendiri dapat memperoleh gambaran yang tepat tentang TOEIC sehingga dapat menentukan strategi yang pas untuk menanklukkan TOEIC.

Membaca adalah salah satu keterampilan berbahasa yang diperlukan untuk diajarkan di kelas bahasa. Siswa harus mampu membaca teks dalam bahasa Inggris, baik untuk karier mereka, untuk belajar, atau hanya untuk kesenangan. Membaca juga memainkan peran penting untuk akuisisi bahasa. Ketika membaca teks-teks yang sangat menarik, proses akuisisi akan lebih berhasil. Membaca teks juga memberikan kesempatan bagi siswa untuk belajar kosakata, tata bahasa, model pengucapan, dan bahkan untuk menulis kalimat, paragraf, dan esai (Harmer, 2005:68)

Teori skema yang dibahas oleh Carrell dan Eisterhold (1987) memberikan gambaran yang jelas tentang sifat atau proses membaca dalam pikiran pembaca. Secara singkat ia menyatakan bahwa memahami teks adalah proses interaktif antara latar belakang pengetahuan pembaca dan teks. Pemahaman yang efisien, dengan demikian, membutuhkan kemampuan untuk menghubungkan latar belakang pengetehuan dengan materi teks (schemata). Untuk meningkatkan kemampuan memahami teks, pembaca harus mengubah kebiasaan membaca kata demi kata dan berfokus kandungan bacaan. (Smith, 1991:9). Dalam perspektif psikolinguistik membaca dianggap sebagai "permaianan tebakan" (Goodman, 1982:135). Pembaca membangun pesan yang dikodekan oleh penulis. Tindakan mengkonstruksi makna berlangsung melalui proses siklus sampling input teks, prediksi, pengujian, dan konfirmasi atau merevisi prediksi tersebut. Dengan menebak pembaca memprediksi, menguji, dan mengkonfirmasi kandungan teks. Ini berarti bahwa pengetahuan latar belakang pembaca sangat penting untuk membantu memahami teks. Peran pengetahuan latar belakang dalam memahami bacaan dikenal sebagai teori skema yang menyatakan bahwa setiap teks (lisan atau tertulis) tidak dengan sendirinya memiliki makna. Sebuah teks hanya menyediakan arah bagi pembaca untuk membangun makna sendiri berdasarkan pengetahuan mereka sebelumnya. (Carrell dan Eisterhold 1978:220; Morley, 2003:74)

Menurut teori skema, memahami teks adalah proses interaktif antara latar belakang pengetahuan pembaca dan teks. Memahami teks melibatkan lebih dari sekedar mengandalkan pengetahuan linguistik seseorang, melainkan melibatkan pengetahuan seseorang tentang dunia juga. Prinsip ini menghasilkan dua mode dasar pengolahan informasi yang disebut bottom-up dan top-down. Dalam strategi bottom up, pembaca terutama mengandalkan pada pengetahuan linguistik untuk memahami teks atau untuk memproses informasi. Ini juga disebut mode berbasis teks atau pengolahan informasi berbasis data. Sementara itu, dalam mode top-down, pembaca mengandalkan pengetahuan mereka sebelumnya atau pengetahuan dunia untuk memahami teks, ini juga sering disebut sebagai modus berbasis pengetahuan atau pengolahan 
informasi berbasis konsep. (Carrell dan Eisterhold 1978:221; Morley, 2003:75)

Berikut makro dan ketrampilan mikro Membaca. Keterampilan mikro membaca meliputi: (1) membedakan antara grafem dan pola ortografi bahasa Inggris; (2) mengenali inti kata-kata, dan menafsirkan pola urutan kata dan maknanya; (3) mengenali kelas kata gramatikal (kata benda, kata kerja, dll.), sistem (misalnya, tenses, agreement, pluralisasi), dan pola kalimat; (4) mengenali bahwa arti tertentu dapat dinyatakan dalam bentuk gramatikal yang berbeda; dan (5) mengenali perangkat kohesif dalam wacana perannya sebagai penanda hubungan klausa.

Adapun keterampilan makro membaca meliputi: (1) mengenali bentuk retorika wacana tertulis, (2) mengenali fungsi komunikatif teks tertulis, menurut membentuk dan tujuan, (3) menyimpulkan konteks yang implisit dengan menggunakan latar belakang pengetahuan, (4) menyimpulkan hubungan antara peristiwa, (5) menyimpulkan sebab dan akibat, dan mendeteksi hubungan antara ide utama dan ide pendukung, (6) membedakan antara makna literal dan tersirat, (7) mendeteksi referensi budaya yang spesifik dan menafsirkannya dalam konteks budaya yang sesuai, dan (8) mengembangkan dan menggunakan berbagai strategi membaca, seperti scanning dan skimming, mendeteksi penanda wacana, menebak arti kata dari konteks, dan mengaktifkan schemata untuk interpretasi teks.

Membaca dapat dikelompokan menjadi membaca perseptif, yaitu memperhatikan komponen dari wacana yang lebih besar seperti huruf, kata, tanda baca dan sejenisnya. Membaca selektif adalah membaca berdasarkan gambar, menjodohkan, benar salah, dan respon pendek. Membaca interaktif adalah interaksi antara teks dan pembaca seperti terjadi dalam teks anekdot, narasi dan deskripsi pendek, memo, resep, dan lainnya. Membaca ektensif merupakan kegiatan membaca teks yang lebih dari satu halaman termasuk artikel profesional, esai, laporan teknis, cerita pendek, dan buku.

Membaca perseptif dapat dites menggunakan kegiatan membaca nyaring, respon tertulis, dan pilihan ganda untuk pasangan minimal (minimal pairs). Membaca selektif dapat dilakukan dengan soal pilihan ganda, menjodohkan, mengedit, pemberian tugas yang dipicu gambar, serta pengisian rumpang kosong. Membaca interaktif dapat dites menggunakan cloze-test, membaca impromptu plus membaca pemahaman, menemukan pikiran utama, mengetes penguasaan idioms, frase, ekspresi, idiom, penarikan simpulan, scanning, tata bahasa, pengabaian akan fakta, gagasan pendukung, serta kosakata yang digunakan dalam konteks. Membaca Interaktif dapat dites menggunakan (1) short answer tasks (pertanyaan terbuka berisi pertanyaan mengenai membaca pemahaman), (2) scanning dengan stimulus artikel berita, esei, laporan teknis, bab dalam sebuah buku, menu, lamaran kerja, table, bagan, dll.), dan mengurutkan. Membaca ekstesif dapat dilakukan dengan membaca impromptu, tugas yang memerlukan jawaban pendek, mengedit, melakukan scanning, mengurutkan, mentransfer informasi, menafsirkan, meringkas dan merespon, serta mencatat dan membuat outline.

Tujuan utama dari membaca adalah pemahaman, yaitu kemampuan menemukan makna bacaan. Dengan demikian, tes keterampilan membaca adalah untuk menguji kemampuan membaca peserta tes. Ada tiga tingkatan utama pemahaman, yaitu tingkat literal, pemahaman interpretif, dan pemahaman kritis. Tingkat pertama, pemahaman literal, adalah yang paling jelas. Pemahaman pada tingkat ini melibatkan makna permukaan saja. Pada tingkat ini, peserta tes diminta untuk mencari informasi dan ide-ide yang secara eksplisit dinyatakan dalam teks. Selain itu, tujuan tes ini juga untuk menguji penguasaan kosakata (Karlin, 1971).

Tingkat kedua adalah pemahaman interpretatif atau referensial. Pada tingkat ini, peserta tes diuji kemampuannnya untuk tidak sekadar memahami apa yang tersurat dalam bacaan (literal) akan tetapi membaca untuk makna yang lebih dalam (tersirat). Mereka harus mampu membaca kritis dan menganalisis dengan cermat apa yang mereka baca. Mereka harus mampu untuk melihat hubungan antara ide-ide dan memahami makna yang tersirat dari ide-ide tersebut. 
Pemahaman interpretatif atau referensial mencakup proses berpikir seperti menarik simpulan, membuat generalisasi, dan memprediksi hasil. Pada tingkat ini beberapa pertanyaan yang menantang dapat ditanyakan seperti: (1) menata ulang ide atau topik yang dibahas dalam teks, (2) menjelaskan tujuan penulis menulis teks, (3) menyimpulakn gagasan utama yang tidak dinyatakan secara eksplisit dalam teks, dan (4) memilih kesimpulan yang dapat disimpulkan dari teks yang telah mereka baca (Potts, 1976)

Akhirnya, tingkat ketiga adalah pemahaman membaca kritis ketika ide-ide dan informasi dievaluasi. Evaluasi kritis dapat dilakukan pada saat pembaca telah memahami ide-ide dan informasi yang disajikan. Pada tingkat ini, peserta tes dapat diuji pada keterampilan membaca seperti berikut: (1) kemampuan untuk membedakan antara fakta dan opini, (2) kemampuan untuk mengenali macam macam teks, dan (3) kemampuan untuk menilai keakuratan informasi yang disajikan dalam teks (Potts, 1976)

Tes pemahaman bacaan dapat berupa tes bentuk uraian dan tes bentuk objektif. Tes bentuk objektif dapat berupa soal benar atau salah, pilihan ganda, isian singkat, dan menjodohkan. Dalam tes bentuk uraian ini, peserta tes diminta untuk menjawab soal dengan uraian dengan memnggunakan bahasanya sendiri secara lugas. Dalam tes jenis ini biasanya pertanyaanpertanyaannya mengandung permasalahan yang memerlukan jawaban dalam bentuk uraian atau penjelasan. Menurut Subino (1987:2) ada dua macam bentuk soal uarain, yaitu: (1) soal yang menuntut jawaban bebas serta cenderung tidak membatasi dan (2) soal yang menuntut jawaban yang membatasi, yaitu soal yang memerlukan jawaban yang cenderung dibatasi atau terikat.

Tes uraian memiliki beberapa kelebihan dibandingkan dengan tes objektif, antara lain: (1) memungkinkan para test menjawab soal secara bebas, (2) merupakan tes yang terbaik dalam mengukur kemampuan menjelaskan, membandingkan merangkum, membedakan, menggambarkan, dan mengevaluasi, (3) merupakan tes yang terbaik untuk mengukur keterampilan mengemukakan pendapat dengan tulisan, (4) memberikan kesempatan bagi testi untuk meningkatkan kemampuan menulis, mengorganisasikan ide serta berfikir secara kritis dan kreatif, dan (5) bila dibandingkan dengan bentuk tes yang lain tes uraian relatif lebih mudah membuatnya (lihat Balitbang Dikbud, 1984:24).

Soal bentuk objekti memiliki bentuk bermacam-macam, antara lain (1) bentuk benar salah (true false), (20 bentuk menjodohkan (matching), (3) bentuk isian (completion), dan (4) bentuk pilihan ganda (multiple choice). Pada prinsipnya, bentuk tes objektif di atas mempunyai kelemahan dan kelebihannya. Hal yang paling menonjol dari model tes ini adalah bahwa bentuk tes objektif dapat mencakup materi yang lebih luas sedangkan bentuk uraian agak sukar untuk mengukur semua materi yang sudah diajarkan karena ruang lingkupnya sangat sempit.

Lebih lanjut, kekuatan model tes objektif, antara lain (1) tepat untuk mengungkapkan hasil belajar yang bertatanan pengetahuan, pemahaman, aplikasi, dan analisis, (2) jawaban yang diberikan dapat menggambarkan ranah tujuan pendidikan menurut Bloom, khususnya ranah cognitive domain sebagaimana yang diungkapkan Gronlund (1985:36) bahwa ...objective test items can be used to measure a variety of knowledge out come ...the most generally useful is the multiple choice items... but other items types also have a place. Dengan kata lain, bahwa butir soal objektif dapat digunakan untuk mengukur berbagai hasil belajar yang berupa pengetahuan. Umumnya yang paling berguna adalah item bentuk pilihan jamak, sementara itu, tipe item objektif yang lainnya mempunyai peran tersendiri.

Dari kedua macam tes yang disebutkan di atas, TOEIC menggunakan model tes objektif. Ada tdua macam bentuk yang dipergunakan, yaitu pilihan ganda dan isian. Bentuk pilihan ganda digunakan pada model tes error recognition dan text comprehension, sedangkan model isian dipergunakan pada model tes completion. 


\section{METODE PENELITIAN}

Lingkup penelitian ini adalah model tes TOEIC, khususnya structure dan reading comprehension yang diambil dari beberapa buku latihan tes TOEIC yang diterbitkan oleh Barron's Educational Series, Prentice Hall, dan Longman. Alasan pemilihan buku ini adalah karena buku buku inilah yang beredar luas di dunia pengajaran bahasa Inggris. Adapun bukubuku tersebut adalah sebagai berikut: (1) Longman Preparation Series for the New TOEIC Test oleh Lin Lougheed (2006); (2) Barron's How to Prepare for the TOEIC Bridge Test Oleh Lin Loughedd (2004); (3) Seven Practice Test for Achieving Higher TOEIC Test Score (Volume 1) oleh Stven A. Stupak (1997); dan (4) Seven Practice Test for Achieving Higher TOEIC Test Score (Volume 2) oleh Stven A. Stupak (1997). Dari seluruh buku ini terdapat 24 model test dan akan diambil 5 set model test secara acak sebagai sampel dalam penelitian ini. Satu model test terdiri dari 100 butir soal; jadi secara keseluruhan ada 500 butir soal yang dijadikan data dalam penelitian ini.

Penelitian ini merupakan studi pustaka yang datanya berupa butir-butir soal TOEIC (khususnya structure dan reading comprehension). Dari sejumlah 500 butir soal yang dijadikan data dalam penelitian ini. Sumber datanya adalah buku latihan TOEIC sebagaimana disebutkan di atas.

Teknik pengumpulan data yang dipakai dalam penelitian ini adalah teknik dokumentasi. Teknik dokumentasi yang dimaksud dalam penelitian ini adalah mencatat dan mendokumentasikan butir soal TOEIC yang terpilih secara random. Butir soal diambil dari sumber data (test preparation books) yang telah ditentukan.

Data yang telah tekumpul selanjutnya dianalisis dengan metode deskriptif interpretatif. Pada prinsipnya ada dua tahapan utama dalam analis ini, yaitu: deskripsi (klasifikasi) dan eksplanasi. Prosedur lengkap dapat digambarkan sebagai berikut: Pertama, data yang telah terkumpul lewat identifikasi kemudian diklasifikasikan berdasarkan dua kategori (structure dan reading comprehension). Selanjutnya, data diklasifikasi menurut aspek linguistik (fungsi dan makna). Pola liguistik ini digunakan untuk melihat tipe butir soal yang ditanyakan dalam butir soal. Tahapan kedua dari analisis data adalah kalkulasi masing masing tipe soal untuk memperoleh gambaran frekuensi dari masing-masing tipe, kategori linguistik mana yang paling dominan. Tahap terakhir adalah pembahasan mengenai implikasi hasil penelitian ini dalam pengajaran TOEIC.

\section{HASIL DAN PEMBAHASAN}

\section{Tipe Pertanyaan pada Butir Soal Completion dan Error Recognition}

Komponen linguistik yang ditanyakan dalam bagian Completion dan Error Recognition meliputi pertanyaan tentang penguasaan vocabulary, Verb tense, Class of words, preposition, Degree of comparison in Adjective, adverb of frequency, conjunction, conditional sentence, dan determiner.

\section{a. Penguasaan Kosakata}

Butir soal pada bagian completion banyak terkait dengan penguasaan kosakata, part of speech, dan penggunaannya yang tepat dalam sebuah kalimat. Untuk itu, peserta tes akan bisa menjawab pertanyaan dengan baik apabila mereka memiliki khasanah kosakata yang memadai dan mampu menggunakannya dalam kalimat secara akurat ketatabahasaanya. Ada sekitar $54 \%$ pertanyaan pada bagian completion dan error recognition terkait dengan kosakata. Bila dilihat secara keseluruhan, terdapat 30\% pertanyaan bagian Reading yang 
meliputi pertanyaan tentang penguasaan kosakata bahasa Inggris. Pertanyaan mengenai kosakata ini meliputi beberapa variasi.

Kosakata yang menjadi pengecoh (distractors) merupakan kosakata yang memiliki kesamaan bentuk (false friend) sebagaimana contoh berikut ini.

The manager requested two ... of the monthly report.
A. Captions
B. Copies
C. Copes
D. Caps

Di samping itu, kosakata yang menjadi pengecoh adalah kosa kata yang memiliki kesamaan arti atau kata yang sama namun berbeda kelas katannya (Verb, noun, adjective, dan $a d v e r b)$ sebagaimana contoh berikut:

Because the equipment is very delicate, it must be handled with
A. Caring
B. Careful
C. Care
D. Carefully

Namun demikian, pada umumnya pertanyaan mengenai kosakata ini benar benar menguji penguasaan perbendaharaan bahasa Inggris peserta tes. Kosakata yang menjadi pengecoh dalam soal tes tidak mudah untuk diprediksi ataupun dipolakan karena tidak memiliki kaitan apapun antara satu dengan yang lain, sebagaimana contoh berikut ini. Dynamic marketing was ... as the reason for the increase in sales.
A. name
B. gave
C. cited
D. saying

\section{b. Verb Tense dan Subject \& Verb Agreement}

Pemahaman ketatabahasaan khususnya verb tense beserta subject dan verb agreement banyak dipertanyakan dalam butir soal bentuk error recognition. Hal ini dapat difahami mengingat verb tense dan subject verb agreement ini merupakan salah satu unsur ketatabahasaan yang penting dalam bahasa Inggris, sebagaimana contoh berikut.

The company ... in 1970 .
A. founded
C. was founded
B. were found
D. has been founded

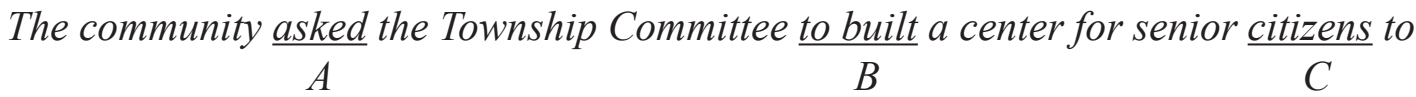
use as a meeting place.

$D$

\section{c. Class of words (Verb, Noun, Adjective)}

Pemahaman class of word sangat penting dalam bahasa Inggris karena bahasa Inggris memiliki proses infleksi dari kata kerja, benda, sifat, dan keterangan, misalnya kata create, creator, creative, creatively, creativity, dsb. Pengetahuan kebahasaan semacam ini sering ditanyakan dalam butir tes TOEIC, sebagaimana contoh berikut ini. 
The patent law became strengthening with the introduction of criminal penalties for $\begin{array}{lll}A & B & C\end{array}$

offenders who submit false documents to support their claims.

D

Visits to the United States complain that the American system of weights and measures A $B$

is both confusing and irrational.

C

$D$

\section{d. Preposition}

Bahasa Inggris memiliki banyak preposisi dibandingkan dengan Indonesia. Oleh karena itu, pemahaman terkait penggunaan preposisi dalam kalimat sangat penting. Pada umumnya pembelajar bahasa Inggris memiliki kesulitan dalam hal penggunaannya. Untuk itu, banyak pertanyaan tentang penggunaan preposisi ini dalam butir soal TOEIC, sebagaimana contoh berikut ini.

The report said that everything was ... control.
A. on
C. over
B. at
D. under

\section{e. Determiner}

Determiner adalah kata atau frase yang nempel pada kata atau frasa benda dan berfungsi untuk mengidentifikasi referensi kata atau frasa benda dalam konteks. Artinya, determiner dapat menunjukkan apakah benda tersebut mengacu pada elemen tertentu atau tidak, pada elemen lebih dekat atau lebih jauh. Jenis umum dari determiner termasuk artikel (a, the, an), demonstratif (seperti this, that), penentu posesif, dan bilangan (many, few, some). Penggunaan determiner dalam kalimat sangat kompleks dan pemahaman tentang hal ini sangat penting. Oleh karena itu, banyak pertanyaan dalam TOEIC mengacu pada determiner, seperti dalam contoh berikut.

(1) The doctor advised me to eat .... apple every morning.
A. A
C. the
B. an
D. that

\section{f. Conjunction}

Conjuction juga merupakan aspek tatabahasa yang mendapat perhation dalam test TOEIC. Banyak butir soal dalam TOEIC mentes pengusaan peserta tentang penggunaan conjuction ini, sebagaimana dalam contoh berikut.

The traffic moved slowly ... of construction.

A. About

B. Always

C. Because

D. Therefore

\section{g. Degree of comparison in Adjective}

Penggunaan kata sifat dalam bahasa Inggris cukup kompleks, khususnya yang terkait dengan derajat dalam Comparasing (degree of comparison) pada level lebih dan paling. Untuk itu aspek ini juga sering ditanyakan dalam tes TOEIC walau frekuensi atau jumlahnya tidak banyak. Berikut contohnya.

The building was the ... in the city. 

A. More
C. bigger
B. Most
D. tallest

\section{h. Conditional sentence}

Kalimat bersarat dalam bahasa inggris memliki bentuk yang cukup kompleks, terutama berkaitan dengan bentuk verb tense-nya. Ada tiga macam bentuk conditional sentence namun dalam penggunaan sehari-hari hanya bentuk pertama dan kedua yang agak produktif. Artinya, banyak digunakan dalam komunikasi sehari hari. Bentuk ini juga sering ditanyakan dalam tes TOEIC walau jumlah atau frekuensinya tidak banyak. Berikut contohnya:

He was sure could get a better job if he tried.

A $\quad B \quad C \quad D$

Tabel 1. Frekuensi Tipe Soal dalam Completion dan Error Recognition

\begin{tabular}{cccccccc}
\hline Aspek yang Ditanyakan & Tes $\mathbf{1}$ & Tes $\mathbf{2}$ & Tes $\mathbf{3}$ & Tes $\mathbf{4}$ & Tes $\mathbf{5}$ & $\mathbf{J m l}$ & $\mathbf{\%}$ \\
\hline $\begin{array}{c}\text { Vocabulary } \\
\text { Class of words (Verb, Noun, }\end{array}$ & 34 & 32 & 32 & 32 & 33 & 163 & 54.34 \\
Adjective, adverb) & 7 & 10 & 10 & 8 & 10 & 45 & 15 \\
$\quad$ Verb tense & 8 & 8 & 5 & 7 & 6 & 34 & 11.33 \\
Determiner & 4 & 2 & 4 & 3 & 3 & 16 & 5.33 \\
Preposition & 2 & 2 & 3 & 3 & 2 & 12 & 4 \\
$\quad$ Conjunction & 2 & 2 & 2 & 2 & 3 & 11 & 3.67 \\
Degree of comparison in & 1 & 2 & 2 & 3 & 2 & 10 & 3.33 \\
Adjective & 2 & 2 & 2 & 2 & 1 & 9 & 3 \\
Conditional sentence & 60 & 60 & 60 & 60 & 60 & 300 & 100
\end{tabular}

\section{Konteks Bacaan pada Butir Soal Pemahaman Teks}

Tipe pertanyaan pada bagian ini mengetes keterampilan memahami, menginterpretasi, dan menganalisis teks bacaan. Tes pemahaman bacaan TOEIC bertujuan untuk menilai kemampuan membaca teks khususnya dalam konteks bisnis. Adapun konteks bacaan yang biasa muncul dalam tes TOEIC antara lain meliputi general business (misalnya pada topik: RETAIL OUTLETS), Manufacturing (misalnya topic: The helping Hand), office (Misalnya topic All Regular Staff), purchasing (Misalnya pada topic: To Our Subscribers), housing (Misalnya pada topic: Notice for Public Hearing), travelling (Misalnya pada topic: Great Fishing Abroad: The Mystic lady), dining out (Misalnya pada topic: LES FAIRES, Rive Gauche Appetizers), entertainment (misalnya pada topic: GET AWAY)

Hasil temuan ini sesuai dengan yang disampaikan oleh Wilson (2000) dalam laporan penelitiannya tentang TOEIC. Wilson menyebutkan konteks bacaan TOEIC meliputi manual, laporan, bentuk, pemberitahuan, iklan, majalah, dan memorandum. Menurut Wilson (2000), surat-surat, berita dan artikel majalah juga digunakan di bagian membaca. Terkait dengan jenis teks ini di bagian pemahaman membaca TOEIC, Razenberg (2003) menyarankan pengajaran di kelas menggunakan silabus berbasis teks untuk mengajar pemahaman bacaan TOEIC. Jenisjenis teks untuk pemahaman bacaan TOEIC ditunjukkan oleh Razenberg (2003) adalah bentukbentuk, grafik tabel, indeks, iklan, fax, memo, buletin, surat-surat, dan lain-lain.

Terkait dengan struktur teks atau organisasi teks, umumnya teks bacaan pada TOEIC memiliki tiga macam stuktur sebagai berikut. Yang pertama adalah Masalah/ Solusi. Pola masalah/ solusi adalah analisis masalah dalam konteks tertentu dan proposisi dari solusi untuk 
masalah ini. Empat fase dalam pola ini adalah situasi, masalah, solusi dan evaluasi. Yang kedua adalah Umum/ Khusus. Pola umum/ khusus adalah teks dengan pernyataan umum dalam pendahuluan dilanjutkan ke detail yang lebih spesifik yang membantu untuk lebih memperjelas pernyataan umum dan maksud penulis. Teks diakhiri dengan ringkasan dari bagian ini. Yang ketiga adalah Klaim/ Konter Klaim. Pola klaim/ Konter klaim adalah sebuah pendekatan untuk menggabungkan argumentasi dalam sebuah bagian, dengan menyediakan klaim atau asumsi, dan menambahkan konter klaim, atau temuan diamati sebenarnya. Yang keempat adalah Pertanyaan/ Jawaban. Pertanyaan/ jawabannya adalah sebuah pertanyaan di awal teks dan diikuti dengan jawaban atas pertanyaan dalam teks.

Temuan ini senada dengan apa yang disampaikan oleh Muller (2007) bahwa struktur teks harus dipertimbangkan untuk pemahaman bacaan TOEIC. Muller (2007) menjelaskan bahwa pemahaman bacaan TOEIC akan efektif diajarkan dengan menggunakan implikasi dari analisis wacana. Dengan mengacu pada pendekatan analitis yang disarankan oleh peneliti seperti McCarthy (1991) dan Belanda dan Johnson (2000), dan Muller (2007) menjelaskan ada empat pola utama pada bagian tes pemahaman bacaan pada TOEIC yaitu masalah/ solusi, umum/ khusus, klaim/ gugatan balik, dan pertanyaan/ jawaban (hal.36).

\section{Tipe Pertanyaan Pemahaman Teks pada Reading TOEIC}

Terkait dengam tipe pertanyaan bacaan TOEIC yaitu hasil analisis menunjukkan ada beberapa pola utama, yaitu:

1. Pertanyaan tentang gagasan utama atau poin bahasan utama pada bacaan, kemungkinan judul yang tepat

What does the above memorandum concern?

a. Results of a meeting

b. Heavy investment losses

c. Bringing in a new investor

d. Withdrawal from unstable markets

2. Pertanyaan tentang informasi yang secara langsung dinyatakan dalam bacaan ini

(3) What is the approximate inflation rate in Latip?
a. 4.5 percent
c. 6.5 percent
b. 5.9 percent
d. 9.0 percent

3. Pertanyaan tentang informasi yang tersirat, disarankan, atau dapat disimpulkan According to the article, what will be a likely result of the negotiations?

a. A shorter workweek

b. Sharply higher wages

c. More paid vacation time

d. Better working conditions

4. Pertanyaan untuk mengenali aplikasi atau tujuan dari penulis

What is the purpose of this notice?

(A) To save on postage costs

(B) To give customers a new phone number

(C) To inform people about the waste crisis

(D) To tell customers they will receive just one catalog 
5. Pertanyaan untuk mengevaluasi bagaimana penulis mengembangkan dan menyajikan bacaan

How does this letter begin?

(A) With an extension of credit

(B) With an expression of regret

(C) With a withdrawal of an offer

(D) With an accounting correction notice

Hasil analisis tentang tipe pertanyaan pada teks bacaan dapat dipaparkan secara singkat pada table di bawah ini.

Tabel 2. Tipe Pertanyaan pada Teks Bacaan

\begin{tabular}{cccccccc}
\hline Reading Text & Tes $\mathbf{1}$ & Tes 2 & Tes 3 & Tes 4 & Tes 5 & JML & \% \\
\hline Gagasan utama & 7 & 7 & 6 & 6 & 6 & 32 & 16 \\
Pertanyaan yang tersirat & 2 & 2 & 2 & 1 & 3 & 10 & 5 \\
Pertanyaan yang tersurat & 29 & 30 & 31 & 32 & 30 & 152 & 76 \\
Aplikasi atau tujuan penulis & 1 & - & 1 & 1 & 1 & 4 & 2 \\
Organisasi text & 1 & 1 & - & - & - & 2 & 1 \\
\hline Jumlah & 40 & 40 & 40 & 40 & 40 & 200 & 100
\end{tabular}

Terkait dengan pola pertanyaan pada reading teks dapat disimpulkan bahwa: (1) pola pertanyaan meengenai apa yang tersurat memiliki jumlah atau frekuensi tertinggi, yaitu $76 \%$; (2) pola pertanyaan mengenai gagasan utanm atau main idea dalam bacaan menduduki peringkat kedua, yaitu sekitar 16\%; (3) pertanyaan mengenai yang tersurat dalam bacaan tidak begitu signifikan, hanya ada 10 atau 5\%; dan (4) pertanyaan mengenai aplikasi atau tujuan penulisan teks dan bagaimana organisasi teks tidak signifikan, masing masing berjumlah $1 \%$ dan $2 \%$.

\section{SIMPULAN}

Penelitian ini berkenaan dengan model tes TOEIC dan bertujuan untuk mendapatkan deskripsi dan penjelasan yang lengkap mengenai sejumlah aspek yang terkait dengan butir butir soal yang terangkum dalam tiga bagian Reading TOEIC yaitu: completion, Error recognition, dan reading comprehension. Secara rinci penelitian ini berupaya untuk (1) Mendekripsikan pola pertanyaan pada butir soal Completion dan Error Recognition pada Reading TOEIC; (2) Mendekripsikan konteks bacaan pada soal pemahaman teks Reading TOEIC; dan (3) Mendekripsikan pola pertanyan pada butir soal pemahaman teks pada Reading TOEIC

Hasil penelitian secara umum menunjukkan sebagai berikut. Pada bagian Reading TOEIC, model tes dibagi menjadi 3 bagian (completion, error recognation, dan reading comprehension). Completion adalah melengkapi kalimat dengan menggunakan komponen ujaran (part of speech) yang harus digunakan dengan tatabahasa yang benar. Adapun error recognition adalah mengidentifikasi kalimat dengan kata-kata yang digarisbawahi benar atau salah adan kata atau frasa yang yang tidak digarisbawahi diasumsikan benar. Secara umum ketiga bagian ini mengetes kemampuan peserta test tentang penguasaan vocabulary, tata bahasa, dan pemahaman teks.

Hasil analisis secara rinci tentang komponen linguistis yang ditanyakan pada bagian Completion dan Error recognition meliputi pertanyaan tentang: penguasaan vocabulary, Verb 
tense, Class of words (Verb, Noun, Adjective), preposition, Degree of comparison in Adjective, adverb of frequency, conjunction, Conditional sentence, dan determiner.

Pola Pertanyaan pada butir oal Completion dan Error Recognition meliputi meliputi pertanyaan tentang: penguasaan vocabulary (54.34\%), Class of words (15\%) (Verb, Noun, Adjective), Verb tense (11.33\%), determiner (5.33\%) preposition (4\%), conjunction (3.67\%), Degree of comparison in Adjective (3.33\%), dan Conditional sentence (3\%). Konteks Bacaan pada Butir Soal Pemahaman Teks adalah konteks bisnis, antara lain meliputi (1) General Business, (2) Manufacturing, (3) Finance and Budgeting, (4) Offices, (5) Personnel, (6) Purchasing, (7) Housing/corporate property, (8) Travel, (9) Dining out, (10) Entertainment, (11) Health.

Pola Pertanyaan Pemahaman Teks pada Reading TOEIC meliputi (1) Pertanyaan tentang gagasan utama atau poin bahasan utama pada bacaan, dan kemungkinan judul yang tepat; (2) Pertanyaan tentang informasi yang secara langsung dinyatakan dalam bacaan ini; (3) Pertanyaan tentang informasi yang tersirat, disarankan, atau dapat disimpulkan; (4) Pertanyaan untuk mengenali aplikasi atau tujuan dari penulis; dan (5) Pertanyaan untuk mengevaluasi bagaimana penulis mengembangkan dan menyajikan bacaan.

Penelitian ini dikhususkan untuk mengkaji butir tes TOEIC pada bagian reading comprehension saja. Oleh karena itu, peneliti selanjutnya dapat mengkaji butir soal TOEIC pada bagian lain, yaitu listening comprehension. Sebagai sumber data peneliti hanya mengambil model tes dari buku yang terdapat pada buku-buku latihan TOEIC yang diterbitkan oleh Longman, Barron, and Prentice Hall. Para peneliti selanjutnya dapat menggunakan sumber data lain dalam kajian selanjutnya.

Berdasarkan hasil penelitian diatas disarankan para pengampu Bahasa Inggris TOEIC untuk memfokuskan kegiatan kelas pada sejumlah komponen linguistik yang meliputi part of speech (verb, noun, pronoun, adjective, adverb, preposition, conjunction, dan interjection), Subject-verb agreement, phrasal verbs, tenses, conjunction, dan preposition. Kegiatan kelas juga harus banyak mengembangkan khazanah kosakata, baik melalui pengajaran secara eksplisit maupun implisit. Latihan membaca difokuskan pada teks bacaan mengenai bisnis sepert general business, office, personnel, purchasing, housing, travelling, dining out, dan entertainment. Adapaun kegiatan membaca diarahkan pada kegiatan untuk mencari gagasan utama, informasi yang tersurat, informasi tersirat, aplikasi ide penulis, evaluasi mengenai bagaimana penulis mengembangkan teks, dan gaya ataupun tone dari teks.

\section{DAFTAR PUSTAKA}

Bachman, Lyle F. 1990. Fundamental Considerations in Language Testing. Oxford: Oxford University Press

Brown, Douglas H. 2004. Language Assessment: Principles and Classroom Practices. New York: Pearson Education.

Educational Testing Service. 2005. “TOEIC Technical Manual”. Retrieved August 27, 2005, from www.toeic.cl/down/toeic_tech_man.pdf.

Celce-Murcia, M., Dörnyei, Z. \& Thurrell, S. 1995. "Communicative Competence: A Pedagogically Motivated Model with Content Specifications". Issues in Applied Linguistics 6/2, 5-35.

Hughes, Arthur. 1989, 2003. Testing for Language Teachers. $2^{\text {nd }}$ ed. Cambridge: Cambridge University Press. 
Iwabe, K. 2005. Untitled Presentation. TOEIC Training Seminar sponsored by IIBC. Osaka, Japan.

Karlin, Robert. 1971. Teaching Elementary Reading: Principles and Strategies. Harcourt Brace and Jovanovich, Inc.

Pandjaitan, Mutiara O. 2003. "Penilaian Berbasis Kelas dengan Portfolio". A Seminar Paper Presented at Indonesia University of Education 2003.

Potts, John. 1976. Beyond Initial Reading. London:George Allen and Unwin Ltd.

Saegusa, Y. 1989. Japanese company workers’ English

Saegusa, Y. 1989. Japanese company workers' English proficiency, WASEDA Studies in Human Sciences, 2, 1-12.Suherdi, Didi and Cece Rakhmat. 1998. Evaluasi Pengajaran. Proyek BP3GSD. Depdikbud RI.

Sukyadi, Didi, 2012. Evaluasi Pembelajaran Bahasa Inggris.

Weir, Cyril. 1993. Understanding and Developing Language Tests. Wilshire: Redwood Books.

Yeonsuk Cho, Educational Testing Service, Rosedale Road, MS 07-R, Princeton, NJ 08541, USA Email: ycho@ets.org

Wilson, K. M., and Graves, K. 1999. "Validity of the Secondary-Level English Proficiency Test at Temple University-Japan (ETS RR-99-11"). Princeton, NJ: Educational Testing Service.

Wilson, K. M., Bell, I., and Berquist, A. 1998. "Guidelines for Comparing Performance on Two Tests of ESL Proficiency: The TOEIC Test and the TOEFL" (Unpublished field study report). Princeton, NJ: Educational Testing Service.

Wilson, K. M., Komarakul, S., and Woodhead, R. 1997. "TOEIC/LPI Relationships in Academic and Employment Contexts in Thailand." Princeton, NJ: Educational Testing Service.

Wilson, K. M. (1989). “Enhancing The Interpretation of a Norm Referenced Second-Language Test Through Criterion Referencing: A Research Assessment of Experience in The TOEIC Testing Context (TOEIC Research Report Number 1 \& ETS RR-89-39)”. Princeton, NJ: Educational Testing Service.

Wilson, K. M., and Chavanich, K. (1989). "Further Evidence of Stability in TOEIC/LPI Relationships Across Diverse Samples (Unpublished field study report)". Princeton, NJ: Educational Testing Service.

Wilson, K. M. (1986). “The Relationship of GRE General Test Scores to Undergraduate Grades: An Exploratory Study for Selected Subgroups" (GRE Board Professional Report No. 8319P and ETS RR-86-37). Princeton, NJ: Educational Testing Service.

Wilson, K. M. (1984). "The Relationship of GRE General Test Scores to Undergraduate Grades" (GRE Board Professional Report GREB No. 81-22P and ETS RR-85-9). Princeton, NJ: Educational Testing Service.

Woodford, P. E. (1982). "The Test of English for International Communication (TOEIC)." In C. Brumfit (Ed.), English for International Communication (pp. 61-72). New York: Pergamon Press. 